\title{
Oral infectivity and bacterial interactions with mononuclear phagocytes
}

\author{
C. L. WELLS*†, B. A. FELTIS*, D. F. HANSON*, R. P. JECHOREK* and S. L. ERLANDSEN $\ddagger$ \\ Departments of *Laboratory Medicine and Pathology, †Surgery, and $\ddagger$ Cell Biology and Neuroanatomy, University of \\ Minnesota, Minneapolis, MN 55455, USA
}

\begin{abstract}
Summary. The purpose of this study was to clarify the association between the oral infectivity of a bacterial strain and its susceptibility to ingestion by mononuclear phagocytes or ability to survive within them. Ten bacterial strains tested-all of known oral infectivity-comprised Salmonella typhimurium, Listeria monocytogenes (three strains), Escherichia coli (two strains), Proteus mirabilis, Enterococcus faecalis, Bacteroides fragilis, and a Bacteroides sp. The phagocytic uptake of each strain was measured as the bacteria to phagocyte ratio after mononuclear phagocytes in mouse peritoneal exudate were permitted to ingest bacteria in vivo for $3 \mathrm{~min}$. The three Listeria strains were the most susceptible to phagocytic uptake and the Salmonella strain was relatively resistant. The intracellular survival of each strain was studied during a subsequent $2 \mathrm{~h}$ in-vitro incubation of the mononuclear phagocytes that had been permitted to ingest bacteria in vivo. The strains with the best intracellular survival were Ent. faecalis and two of the three Listeria strains. The ability of $S$. typhimurium to survive intracellularly was intermediate but better than that of the two E. coli strains. Oral infectivity was not consistently correlated with susceptibility to ingestion by mononuclear phagocytes or ability to survive within them.
\end{abstract}

\section{Introduction}

Different species or strains of enteric bacteria vary in invasiveness. ${ }^{1-2}$ Pathogenic organisms such as Salmonella spp. and Listeria monocytogenes given by the natural (oral) route are able to migrate ("translocate") from the intestine to other sites, such as the liver and spleen, and cause systemic disease. ${ }^{2-6}$ Translocation of potentially pathogenic members of the normal intestinal microflora, such as Escherichia coli, Klebsiella pneumoniae, Proteus mirabilis, Pseudomonas aeruginosa and Enterococcus faecalis, can be induced by bringing about intestinal overgrowth. This has been studied in gnotobiotic mice $e^{6-10}$ and in antibiotictreated rodents colonised with an antibiotic resistant strain. ${ }^{11-17}$ Normal animals are resistant to overgrowth and to translocation of such bacteria given orally, even in large doses. ${ }^{13-14,16,18}$ Relatively non-pathogenic, strictly anaerobic members of the normal intestinal flora such as Bacteroides spp. can rarely be induced to translocate, even in gnotobiotic mice with high intestinal concentrations of the organism ${ }^{7-8}$ or in antibiotic-treated rodents with intestinal overgrowth of an antibiotic resistant strain. ${ }^{17}$

Earlier studies showed that mononuclear phagocytes could transport inert particles ( $1 \mu$ m latex beads) and possibly viable bacteria from the intestinal lumen to the draining mesenteric lymph node (MLN). ${ }^{19} \mathrm{~A}$ similar mechanism of particle transport had been described for alveolar macrophages migrating from the terminal alveolus of the lung to the draining tracheobronchial lymph node. ${ }^{20}$ Because Salmonella spp. and L. monocytogenes can survive and possibly replicate in phagocytic leucocytes, ${ }^{21-23}$ and because they readily translocate from the intestine, it seemed reasonable to speculate that facultative intracellular parasitism is associated with oral infectivity.

Thus, the aim of this study was to determine if the oral infectivity of a bacterial strain was related to the susceptibility of that strain to ingestion by mononuclear phagocytes or its ability to survive within them.

\section{Materials and methods}

\section{Mice}

Female Swiss Webster mice (18-22 g; HarlanSprague Dawley, Inc., Indianapolis, IN, USA) were used in all experiments.

\section{Bacteria}

Bacterial strains were chosen for their strong or weak ability to produce systemic infection in orally 
Table I. Oral infectivity of 10 bacterial strains for mice, expressed as the recovery of viable organisms from mesenteric lymph node (MLN) and liver

\begin{tabular}{|c|c|c|c|}
\hline \multirow[b]{2}{*}{ Bacterial strain } & \multicolumn{2}{|c|}{ Oral infectivity* for } & \multirow[b]{2}{*}{ Reference } \\
\hline & $\begin{array}{l}\text { mice in whose } \\
\text { caeca the infecting } \\
\text { organism was } \\
\text { present at } \\
<10^{7} / \mathrm{g}\end{array}$ & $\begin{array}{l}\text { gnotobiotic or } \\
\text { antibiotic-treated mice } \\
\text { in whose caeca the } \\
\text { infecting organism was } \\
\text { present at } 10^{10-11} / \mathrm{g} \dagger\end{array}$ & \\
\hline S. typhimurium 14028 & $+t+$ & ND & table II \\
\hline L. monocytogenes $+\mathrm{Hla}$ & ++ & ND & table II \\
\hline L. monocytogenes $-\mathrm{Hla}$ & + & ND & table II \\
\hline L. monocytogenes $+\mathrm{H} 4 \mathrm{~b}$ & + & ND & table II \\
\hline Ent. faecalis M20 & Nil $\ddagger$ & $++t$ & $8,10,13-14$ \\
\hline E. coli $\mathrm{C} 25$ & Nil & ++ & $6-8,11,16$, table III \\
\hline E. coli $\mathbf{M} 14$ & Nil & ++ & 8,10 \\
\hline P. mirabilis $\mathbf{M} 13$ & Nilf & ++ & 8,10 \\
\hline B. fragilis 9032 & Nil & + & table III \\
\hline Bacteroides sp. M25 & Nilt & + & 17 \\
\hline
\end{tabular}

ND, not done.

$*+++$, Bacterial strain recovered from the MLN and liver of the majority of mice, with occasional deaths; ++ , bacterial strain recovered from the MLN of the majority of mice, and from the liver of at least an occasional mouse, with no mortality; + , bacterial strain recovered from the MLN of at least an occasional mouse, with no mortality.

+Caecal overgrowth followed either oral inoculation of the bacterial strain into gnotobiotic mice, or oral inoculation of an antibiotic-resistant strain into antibiotic-treated mice.

$\ddagger$ High numbers (e.g., $10^{9}$ ) given orally are rapidly eliminated from the gut. The strain is either not recovered from extra-intestinal tissues, or recovered from the MLN of an occasional mouse. ${ }^{10,14,16,18}$

Table II. Caecal colonisation and oral infectivity of $S$. typhimurium 14028 and L. monocytogenes (three strains) in normal mice killed $48 \mathrm{~h}$ after oral administration of $10^{9}$ bacteria

\begin{tabular}{|c|c|c|c|c|c|c|c|c|}
\hline \multirow{4}{*}{$\begin{array}{l}\text { Oral } \\
\text { inoculum }\end{array}$} & \multicolumn{3}{|c|}{$\begin{array}{c}\text { Mean } \log _{10}(\mathrm{SEM}) \text { viable bacteria } / \mathrm{g} \\
\text { caecum }(n=6)\end{array}$} & \multirow{3}{*}{\multicolumn{2}{|c|}{$\begin{array}{l}\text { No }(\%) \text { of } \\
\text { mice, in groups of } 21- \\
24 \text {, yielding infecting } \\
\text { organisms* from }\end{array}$}} & \multirow{2}{*}{\multicolumn{2}{|c|}{$\begin{array}{l}\text { Mean } \log _{10}(\mathrm{SEM}) \\
\text { viable bacteria in }\end{array}$}} & \multirow{4}{*}{$\begin{array}{l}\text { Mortality } \\
(\%)\end{array}$} \\
\hline & \multirow{3}{*}{$\begin{array}{l}\text { Aerobic and } \\
\text { facultative } \\
\text { gram-negative } \\
\text { bacilli }\end{array}$} & \multirow{3}{*}{$\begin{array}{l}\text { Aerobic and } \\
\text { facultative } \\
\text { gram-positive } \\
\text { bacteria }\end{array}$} & \multirow{3}{*}{$\begin{array}{c}\text { Strict } \\
\text { anaerobes }\end{array}$} & & & & & \\
\hline & & & & & & \multirow{2}{*}{ MLN } & \multirow{2}{*}{ liver } & \\
\hline & & & & MLN & liver & & & \\
\hline Saline & $5 \cdot 4(0 \cdot 1)$ & $7 \cdot 8(0 \cdot 3)$ & $9 \cdot 3(0 \cdot 2)$ & $0 / 24(0)$ & $0 / 24(0)$ & - & - & $0 / 24(0)$ \\
\hline S. typhimurium 14028 & $6.4(0.3) \dagger$ & $8 \cdot 2(0 \cdot 2)$ & $9.4(0.2)$ & $19 / 21(90)_{+}^{+}$ & $12 / 21(57) \S$ & $3 \cdot 3(0 \cdot 2)$ & $2 \cdot 4(0.3)$ & $3 / 24(13)$ \\
\hline L. monocytogenes $+\mathrm{Hla}$ & $4.5(0 \cdot 6)$ & $8 \cdot 2(0 \cdot 1)$ & $9.4(0.2)$ & $12 / 23(52) \uparrow$ & $13 / 23(57) \S$ & $3.4(0.2)$ & $2 \cdot 9(0.3)$ & $0 / 23(0)$ \\
\hline L. monocytogenes - $\mathrm{Hla}$ & $5 \cdot 1(0.5)$ & $8 \cdot 2(0 \cdot 2) \|$ & $9 \cdot 3(0 \cdot 1)$ & $0 / 24(0)$ & $0 / 24(0)$ & - & - & $0 / 24(0)$ \\
\hline L. monocytogenes $+\mathrm{H} 4 \mathrm{~b}$ & $5 \cdot 3(0.3)$ & $8.5(0.1)$ & $9 \cdot 1(0 \cdot 1)$ & $4 / 24(17)$ & $3 / 24(13)$ & $1.8(0 \cdot 2)^{* *}$ & $2 \cdot 2(0 \cdot 8)$ & $0 / 24(0)$ \\
\hline
\end{tabular}

*The orally administered strain was the only organism recovered from MLN or liver.

$+S$. typhimurium was the predominant species in all mice tested.

+Significantly greater than in mice given + Hla $(p<0.05)$ and all other inocula $(p<0.01)$.

\$Significantly greater than in mice given saline, $-\mathrm{Hla}$, or $+\mathrm{H} 4 \mathrm{~b}(\mathrm{p}<0.01)$.

$\| L$. monocytogenes present in the caecal flora (up to $10^{5} / \mathrm{g}$ ) of individual mice as shown by growth on listeria selective agar.

ISignificantly greater than in mice given $+\mathrm{H} 4 \mathrm{~b}(\mathrm{p}<0.05),-\mathrm{Hla}(\mathrm{p}<0.01)$ or saline $(\mathrm{p}<0.01)$.

** Significantly less than the number recovered from mice inoculated with 14028 or $+\mathrm{H} 1 \mathrm{a}(\mathrm{p}<0 \cdot 01)$.

infected mice. The ability of each strain to migrate from the intestine has either been previously recorded, or is presented here (tables I, II and III). S. typhimurium ATCC 14028, L. monocytogenes ATCC 43249 serotype $1 / 2 \mathrm{a}$, and L. monocytogenes ATCC 43248 serotype 1/2a were obtained from the American Type Culture Collection, Rockville, MD, USA. S. typhimurium 14028 has been reported to be virulent for mice by intraperitoneal inoculation. ${ }^{24-25}$ The two $L$. monocytogenes strains were derived from a single parent strain isolated from a guinea-pig lymph node. ${ }^{26}$ L. monocytogens 43248 (termed - Hla) is a spontaneous non-haemolytic variant of its wild-type counterpart 43249 (termed $+\mathrm{H} 1 \mathrm{a}$ ); these two strains are identical in all characters tested so far except for haemolysin production, mouse virulence, invasiveness in cultured epithelial cells and phospholipase production. ${ }^{4,26-27}$ L. monocytogenes CDC G283 serotype $4 \mathrm{~b}$ (termed $+\mathrm{H} 4 \mathrm{~b}$ ), isolated in a food-borne outbreak of listeriosis, was obtained from the Centers for Disease Control, Atlanta, GA, USA. Both L. monocytogenes $+\mathrm{Hla}$ and $+\mathrm{H} 4 \mathrm{~b}$, but not $-\mathrm{H} 1 \mathrm{a}$, were haemolytic when grown on Tryptic Soy Agar (Difco) supplemented with sheep blood $5 \%$. B. fragilis VPI 9032, a human clinical isolate, was obtained from the Department of Anaerobic Microbiology, Virginia 
Table III. Caecal colonisation and oral infectivity of $E$. coli $\mathrm{C} 25$ and $B$. fragilis 9032 in antibiotic-treated mice killed $48 \mathrm{~h}$ after oral administration of $10^{9}$ bacteria

\begin{tabular}{|c|c|c|c|c|c|c|}
\hline \multirow[b]{2}{*}{$\begin{array}{l}\text { Oral } \\
\text { inoculum* }\end{array}$} & \multicolumn{4}{|c|}{ Mean $\log _{10}(\mathrm{SEM})$ viable bacteria/g caecum $(n=6-7)$} & \multirow{2}{*}{$\begin{array}{l}\text { Number of mice } \\
(\%) \text { in groups } \\
\text { of } 19 \text { and } 22 \\
\text { yielding infecting } \\
\text { organism } \\
\text { from MLN } \dagger\end{array}$} & \multirow{2}{*}{$\begin{array}{c}\text { Mean } \log _{10} \\
\text { (SEM) } \\
\text { viable } \\
\text { bacteria } \\
\text { in MLN } \dagger\end{array}$} \\
\hline & $\begin{array}{c}\text { Aerobic and } \\
\text { facultative } \\
\text { gram-negative } \\
\text { bacilli }\end{array}$ & $\begin{array}{l}\text { Aerobic and } \\
\text { facultative } \\
\text { gram-positive } \\
\text { bacteria }\end{array}$ & $\begin{array}{c}\text { Strict } \\
\text { anaerobes }\end{array}$ & $\begin{array}{l}\text { Infecting } \\
\text { organism } \ddagger\end{array}$ & & \\
\hline $\begin{array}{l}\text { Saline } \\
E \text {. coli C25 } \\
B \text {. fragilis } 9032\end{array}$ & $\begin{array}{c}6 \cdot 2(0 \cdot 5) \\
10 \cdot 2(0 \cdot 1) \S \\
7 \cdot 3(1 \cdot 2)\end{array}$ & $\begin{array}{l}7 \cdot 8(0 \cdot 3) \S \\
4 \cdot 6(0 \cdot 5) \\
4 \cdot 8(0 \cdot 9)\end{array}$ & $\begin{array}{c}8.7(0.2) \\
\text { None detected } \\
10.5(0.1) \S\end{array}$ & $\begin{array}{c}-\overline{10}(0 \cdot 1) \\
10 \cdot 3(0 \cdot 2)\end{array}$ & $\begin{array}{c}- \\
17 / 22(77) \| \\
5 / 19(26)\end{array}$ & $\begin{array}{l}-\overline{(0 \cdot 1)} \\
1 \cdot 1(0 \cdot 1)\end{array}$ \\
\hline
\end{tabular}

*Before oral inoculation with $E$. coli $\mathrm{C} 25$ or $B$. fragilis 9032 , mice were treated for 3 days with bacitracin and streptomycin or penicillin and neomycin, respectively.

†Indigenous caecal bacteria (streptomycin-sensitive $E$. coli or an Enterobacter sp.) were also recovered (10-80 bacteria/MLN) from four of 24 saline-treated mice, four of $22 \mathrm{E}$. coli-treated mice, and two of $19 \mathrm{~B}$. fragilis-treated mice.

$\ddagger E$. coli $\mathrm{C} 25$ was enumerated on MacConkey agar supplemented with streptomycin $100 \mu \mathrm{g} / \mathrm{ml}$, and $B$. fragilis 9032 on bacteroides bile esculin agar. Caecal organisms from control mice gave negligible growth on these media.

$\S$ Significantly increased compared to the other two treatment groups $(\mathrm{p}<0.01)$.

$\|$ Significantly greater than in mice given $B$. fragilis $9032(\mathrm{p}<0.01)$.

Polytechnic Institute and State University, Blacksburg, VA, USA. E. coli C25, a streptomycin-resistant, human clinical isolate, was obtained from Dr R. Berg, Louisiana State University, Shreveport, LA, USA; this strain has been widely used in studies of bacterial translocation in rodents. ${ }^{6-8,11,16}$ The remaining strains were isolated from Swiss Webster mice during studies of intestinal bacterial translocation in our laboratory. ${ }^{16-17}$ All bacterial strains were maintained at $-70^{\circ} \mathrm{C}$ in Brain Heart Infusion Broth (Difco) supplemented with glycerol $10 \%$, except the Bacteroides strains which were maintained at $-70^{\circ} \mathrm{C}$ in Cooked Meat Broth ${ }^{28}$ (Difco).

\section{Extracellular haemolysin production by L. monocytogenes}

Production of extracellular haemolysin (listeriolysin) by L. monocytogenes was assayed by the method of Tabouret et al ${ }^{29}$ with minor modifications. Filtersterilised supernates from 24-h Tryptic Soy Broth (Difco) cultures were diluted in phosphate-buffered saline supplemented with $6 \mathrm{mM}$ cysteine hydrochloride, incubated for $30 \mathrm{~min}$ at $35^{\circ} \mathrm{C}$ to activate the haemolysin, ${ }^{30}$ mixed 9 parts to 1 part with washed sheep red blood cells (RBCs) $10 \%$, incubated at $35^{\circ} \mathrm{C}$ for $30 \mathrm{~min}$ and centrifuged to pellet the RBCs; the degree of haemolysis was measured as the absorbance at $540 \mathrm{~nm}$. Haemolytic units were expressed as the highest dilution of bacterial supernate showing $50 \%$ haemolysis.

Oral infectivity of B. fragilis $9032, E$. coli $C 25, S$. typhimurium 14028 and L. monocytogenes $+H 1 a$, $-H 1 a,+H 4 b$

In this paper, oral infectivity is defined as the ability of an organism to translocate to extra-intestinal tissues (MLN and liver) after oral inoculation. Separate groups of mice were inoculated orally, by means of a "feeding needle", with $0.1 \mathrm{ml}$ of suspensions con- taining $\log _{10} 9$ saline-washed cells of B. fragilis, E. coli, $S$. typhimurium or L. monocytogenes (strain $+\mathrm{Hla}$, $-\mathrm{H} 1 \mathrm{a}$, or $+\mathrm{H} 4 \mathrm{~b}$ ). All bacterial cells were obtained from overnight tryptic soy broth cultures grown aerobically, with the exception of $B$. fragilis which was grown anaerobically in supplemented ${ }^{28}$ brain heart infusion broth. Control mice were inoculated with saline. To facilitate intestinal colonisation with streptomycin-resistant $E$. coli $\mathrm{C} 25$, mice were given drinking water containing bacitracin (Sigma) $2 \mathrm{mg} / \mathrm{ml}$ and streptomycin sulphate (Sigma) $2 \mathrm{mg} / \mathrm{ml}$ for 3 days before oral inoculation. To facilitate intestinal colonisation with penicillin-resistant $B$. fragilis 9032 , mice were given drinking water containing penicillin $G$ (Sigma) 200 units $/ \mathrm{ml}$ and neomycin sulphate (Upjohn Co.) $4 \mathrm{mg} / \mathrm{ml}$ for 3 days before oral inoculation. Mice were killed 2 days after oral inoculation. In mice given antibiotics, the treatment was continued for the duration of the experiment. Viable bacteria in the caecum (tissue with contents), MLN and liver were counted and identified as previously described. ${ }^{13-16}$ For the selective isolation of the orally inoculated strains from the caecal flora, caeca were also plated as appropriate on listeria selective agar, ${ }^{31}$ MacConkey agar supplemented with streptomycin $100 \mu \mathrm{g} / \mathrm{ml}^{15-16}$ or Bacteroides Bile Esculin Agar ${ }^{28}$ (Difco). The limits of detection of the assays were 10 bacteria/MLN, 15 bacteria/liver, and 500 bacteria/caecum. The combined results of two separate experiments are presented (11-18 mice/treatment group in each experiment). MLN from all mice in all experiments were examined. Livers were examined from all mice in experiments with salmonella and listeria. The caecal microflora was characterised in three or four mice/treatment group in each of the two experiments.

\section{In-vivo phagocytic uptake and in-vitro intracellular survival of bacteria in mononuclear phagocytes}

Bacterial uptake and intracellular survival in mononuclear phagocytes were assayed by the method of 
Leijh et al ${ }^{32}$ with minor modifications as described previously. ${ }^{33}$ Briefly, mice were given an intraperitoneal injection of $1 \mathrm{ml}$ of proteose peptone $10 \%$ in tap water, and $48 \mathrm{~h}$ later an intraperitoneal injection $(1 \mathrm{ml})$ of $\log _{10} 8$ saline-washed bacteria of a single strain, prepared as described for oral inoculation (above). After 3 min (the time of maximal phagocytic uptake $^{32}$ ), mice were killed by cervical dislocation, and peritoneal exudate cells were harvested in ice-cold Hanks's balanced salts solution containing gelatin $0.1 \%$, washed at least four times $(4 \mathrm{~min}, 110 \mathrm{~g}$ ) in the same medium, and resuspended in $4 \mathrm{ml}$ to a concentration of $7 \times 10^{6}$ cells $/ \mathrm{ml}$. After the final wash, the numbers of bacteria in the supernates were 10-100fold lower than the corresponding numbers of intracellular bacteria and, therefore, were unlikely to interfere with assay of the latter. As in previous reports ${ }^{32-34}$ Wright-Giemsa stains demonstrated that c. $80 \%$ of the peritoneal exudate cells were macrophages, with $\geqslant 95 \%$ viability as determined by both propidium iodide and trypan blue dye exclusion. This preparation of peritoneal exudate cells will be termed mononuclear phagocytes for the purposes of the present report. Washed mononuclear phagocytes were agitated by rotation of the suspension at $4 \mathrm{rpm}$ at $37^{\circ} \mathrm{C}$ for a maximum of $120 \mathrm{~min}$. At various time intervals, a 0.5 -ml sample was removed, mixed with $0.5 \mathrm{ml}$ of icecold Hanks's balanced salts solution and centrifuged for $4 \mathrm{~min}$ at $110 \mathrm{~g}$; the cell pellet was then resuspended in $1 \mathrm{ml}$ of bovine serum albumin (Sigma) $0.01 \%$ in icecold distilled water and subjected to lysis by three cycles of freezing and thawing in liquid nitrogen and warm $\left(37^{\circ} \mathrm{C}\right)$ water. Complete lysis of phagocytes was verified microscopically. The numbers of viable intracellular bacteria were determined, after serial dilution in phosphate-buffered saline, by appropriate culture methods. ${ }^{35}$

At the initial time point in this assay $(0 \mathrm{~min})$, phagocytic uptake was measured by calculating the bacteria to phagocyte ratio ("phagocytic index") ${ }^{36}$ By the method of Leijh et al., ${ }^{32}$ the rate constant $\left(\mathrm{K}_{\mathrm{k}}\right)$ for in-vitro intracellular killing between 0 and $120 \mathrm{~min}$ was calculated as: $\mathrm{K}_{\mathrm{k}}=\left[\ln \mathrm{N}_{(\mathrm{t}=0)}-\ln \mathrm{N}_{(\mathrm{t})}\right] / \mathrm{t}$ where $\mathrm{N}$ was the number of bacteria and $t$ was the time in minutes.

Four points should be borne in mind. Firstly, the two anaerobic Bacteroides strains could be used in this assay despite the aerobic incubation because there was no loss of viability after exposure of either strain to atmospheric oxygen for $24 \mathrm{~h}$. Secondly, the fate of intracellular bacteria had to be interpreted in a dynamic milieu in which phagocytes could still continue to ingest extracellular bacteria. ${ }^{3}$ Assessment of viable intracellular bacteria is reliable only when they exceed the extracellular bacteria by $10-100$ times. $^{32}$ Assay of intracellular bacteria was not possible after $120 \mathrm{~min}$ because the numbers of extracellular bacteria in the leucocyte supernates increased substantially, probably due to phagocyte degradation and liberation of viable bacteria, coupled with continued multipli- cation. In addition, the number of peritoneal exudate cells decreased by at least $50 \%$ from 120 to $240 \mathrm{~min}$ and the cell suspension began to stick to the sides of the test tube, presumably due to a release of leucocyte DNA. Thirdly, repeated centrifugation was used to decrease the numbers of extracellular bacteria in the leucocyte suspensions. Some investigators have used antibiotics to kill extracellular bacteria (e.g., gentamicin to kill extracellular listeria ${ }^{37-38}$ ), but we found, as have others, ${ }^{39-40}$ that gentamicin affected the viability of intracellular bacteria. Finally, adherent macrophages were not used because they might have decreased listericidal activity. ${ }^{41}$

\section{Scanning electronmicroscopy of peritoneal exudate cells}

Preparations of washed mononuclear phagocytes, containing viable intracellular bacteria, were viewed by scanning electronmicroscopy to determine if bacteria were adherent to the leucocytes. Washed mononuclear phagocytes were fixed in $0.1 \mathrm{M}$ cacodylate buffer containing glutaraldehyde $3 \%$, dehydrated in ethanol, critical-point dried with $\mathrm{CO}_{2}$, sputter-coated with gold palladium, and examined at $20 \mathrm{kV}$ with a Hitachi S-450 scanning electronmicroscope.

\section{Statistical analysis}

Statistical analyses were performed with StatView $\mathrm{SE}+$ Graphics (Abacus Concepts, Berkeley, CA, USA). Bacterial numbers $\left(\log _{10}\right.$ transformed), phagocytic indices, and intracellular killing constants $\left(\mathrm{K}_{\mathrm{k}}\right)$ were analysed by a one-way analysis of variance followed by Fisher's test for least significant difference. Mice with no detectable bacteria in MLN or liver were not considered in computing the differences in the numbers of bacteria in these sites among various treatment groups. The frequency of bacterial recovery from MLN and liver was determined by $\chi^{2}$ analysis with continuity correction.

\section{Results}

Quantitation of extracellular haemolysin production by listeria

The haemolytic properties (see above) of the three strains of $L$. monocytogenes were confirmed by four separate assays, all of which showed 512, 256 and 32 units of extracellular haemolysin for strains $+\mathrm{Hla}$, $+\mathrm{H} 4 \mathrm{~b}$ and $-\mathrm{H} 1 \mathrm{a}$, respectively.

\section{Oral infectivity of S. typhimurium 14028 and L. monocytogenes $+\mathrm{Hla},-\mathrm{Hla}$ and $+\mathrm{H} 4 \mathrm{~b}$}

Table II shows the caecal colonisation and oral infectivity of S. typhimurium 14028 and L. monocytogenes $+\mathrm{H} 1 \mathrm{a},-\mathrm{H} 1 \mathrm{a}$ and $+\mathrm{H} 4 \mathrm{~b}$. Oral inoculation with $\log _{10} 9$ viable cells had little effect on the caecal 


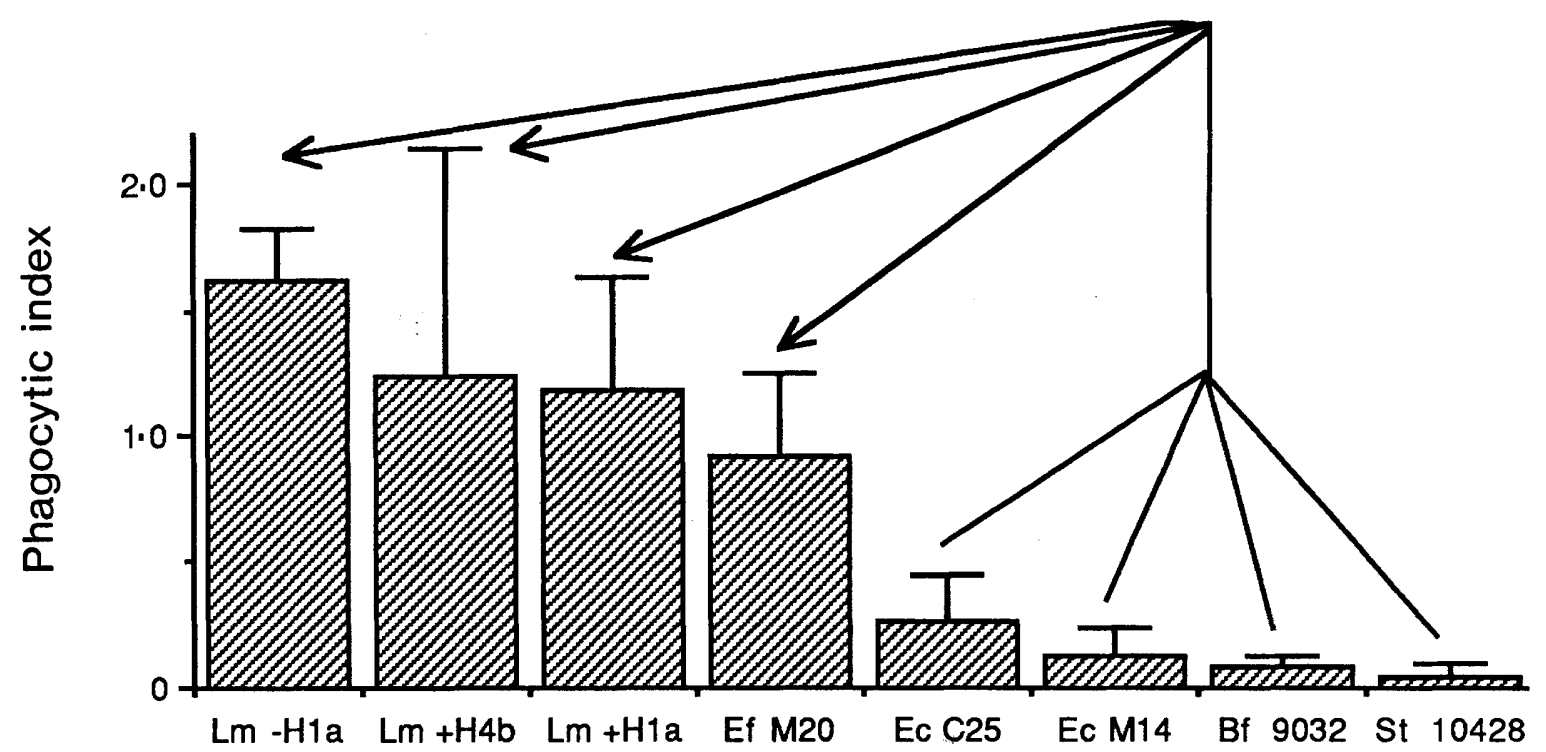

Strain no.

Fig. 1. Phagocytic uptake of strains expressed as the number of viable intracellular bacteria/ml divided by the number of mouse peritoneal mononuclear phagocytes $/ \mathrm{ml}$ (standardised to $7 \times 10^{6}$ ). Intracellular bacteria were obtained from phagocytes that had been permitted to ingest bacteria in vivo for $3 \mathrm{~min}$. Each value represents the mean of 5-9 separate assays; bars are $95 \%$ confidence intervals. Significant differences ( $p<0.05-0.01$ ) occurred between any two strains that can be connected by a line that starts without an arrowhead and ends with an arrowhead. Lm, L. monocytogenes; Ef, Ent. faecalis; Ec, E. coli; Bf, B. fragilis; St, S. typhimurium.

microflora except for S. typhimurium, which became the predominant facultative gram-negative organism. Also, the total numbers of caecal facultative gramnegative bacilli were 10 -fold greater in mice inoculated with $S$. typhimurium than in control mice, but this was not statistically significant. S. typhimurium was recovered in relatively high numbers from the MLN of nearly every mouse and from the liver of $c .50 \%$, and occasional mortality was observed (table II).

Each of the three L. monocytogenes strains colonised the caecum in relatively low numbers; there was considerable animal to animal variation, from no detectable listeria to a maximum of $\log _{10} 5 / \mathrm{g}$ of caecum (table II). There were no noticeable differences in intestinal colonisation by the three strains. However, a spectrum of oral infectivity was observed: $-\mathrm{H} 1 \mathrm{a}$ was not recovered from the MLN or liver of any mouse, $+\mathrm{H} 4 \mathrm{~b}$ was recovered from the MLN and liver of an occasional mouse, and $+\mathrm{H} 1 \mathrm{a}$ was recovered in relatively high numbers from the MLN and liver of $c .50 \%$ of mice. There were no deaths in mice inoculated with the L. monocytogenes strains.

\section{Oral infectivity of $B$. fragilis 9032 and E. coli $C 25$}

Table III shows the caecal colonisation and oral infectivity of $B$. fragilis 9032 and $E$. coli $\mathrm{C} 25$. Neither strain could be expected to colonise the caecum without the administration of antibiotic, or to translocate to the MLN in the absence of caecal overgrowth. ${ }^{10,14,16,18}$ Therefore, mice were treated with bacitracin and streptomycin to enhance caecal colonisation of $E$. coli $\mathrm{C} 25$ (table III) and induce caecal overgrowth. ${ }^{6,8,11,16}$ To compare the translocation of $B$. fragilis present in similarly high caecal concen- trations, 36 mice were treated with neomycin and penicillin and the caecal concentration of $B$. fragilis was monitored in each animal. Although there was considerable animal to animal variation, 19 of 36 treated mice were colonised with $B$. fragilis at concentrations of $\log _{10} 9 \cdot 8-10 \cdot 9 / \mathrm{g}$ of caecum. In these mice, translocation of bacteria to the MLN was, as expected, less striking than in animals colonised by $E$. coli (table III). In this experiment, the liver was not cultured because high caecal concentrations of $E$. coli or $B$. fragilis do not usually induce systemic spread..$^{6-7,10-11}$

\section{Uptake of eight strains of intestinal bacteria by peritoneal mononuclear phagocytes}

Fig. 1 presents the phagocytic index of eight strains of intestinal bacteria with varying oral infectivity (table I). L. monocytogenes $-\mathrm{H} 1 \mathrm{a}$ was ingested more efficiently than the other strains; $1 \mathrm{ml}$ of a suspension of peritoneal mononuclear cells $\left(7 \times 10^{6}\right.$ cells $\left./ \mathrm{ml}\right)$ contained an average of $\log _{10} 7 \cdot 1$ listeria. S. typhimurium 14028 was one of the least efficiently ingested strains; $1 \mathrm{ml}$ of mononuclear cell suspension contained an average of only $\log _{10} 5$ salmonella. The general observation was that phagocytic uptake (fig. 1) was not consistently correlated with oral infectivity (table I).

One $\mathrm{ml}$ of peritoneal mononuclear cell suspension contained an average of $\log _{10} 4.4$ and 4 of $P$. mirabilis and Bacteroides sp., respectively $(\mathrm{n}=6)$. These data are not presented as phagocytic indices in fig. 1 because repeated centrifugation failed to produce a concentration of extracellular bacteria 10 -fold lower than the corresponding concentration of intracellular bacteria. Therefore, we concluded that the phagocytic indices of 


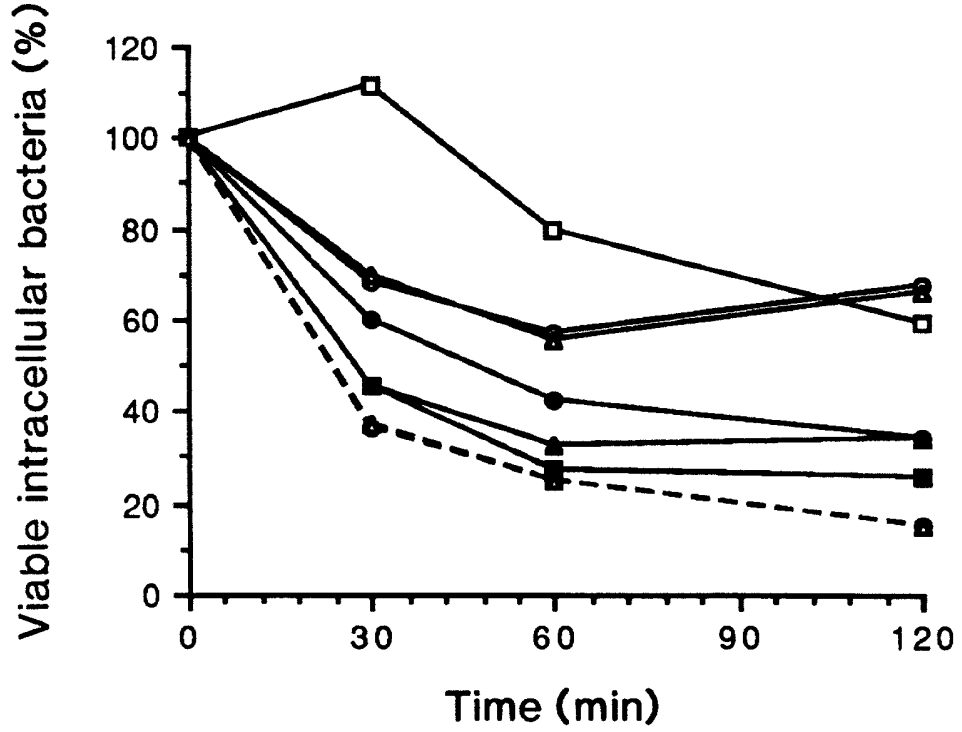

Fig. 2. Percentage survival of strains of bacteria incubated in vitro with mouse mononuclear phagocytes for $0,30,60$ and 120 min (mean values of 4-7 separate assays): - $-\mathrm{O}-L$. monocytogenes $+\mathrm{Hla},-\quad-$ Ent. faecalis $\mathrm{M} 20,-\square-$ L. monocytogenes $-\mathrm{H} 1 \mathrm{a}$, - S. typhimurium $10428,-\Delta-$ L. monocytogenes $+\mathrm{H} 4 \mathrm{~b},-\mathbf{B}-B$. fragilis $9032,--\mathrm{O}_{--}$E. coli $\mathrm{M} 14,--\triangle-E$. coli $\mathrm{C} 25$

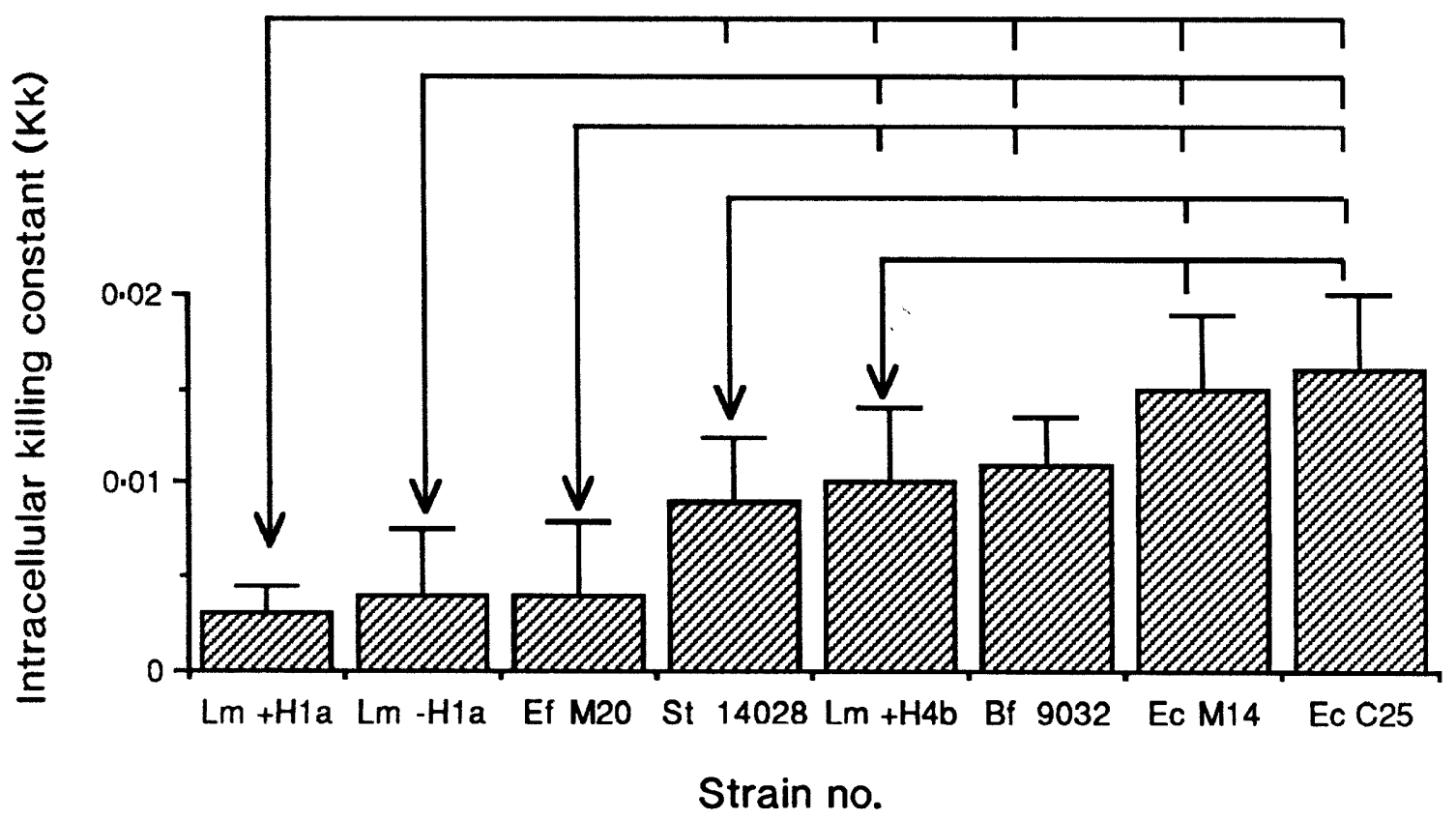

Fig. 3. Survival of strains incubated for $120 \mathrm{~min}$ in vitro with mouse mononuclear phagocytes. Survival expressed as the intracellular killing constant $\left(K_{k}\right)$. Each value represents the mean of $5-9$ separate assays; bars are $95 \%$ confidence intervals. Significant differences ( $p<$ $0.05-0.01)$ occurred between any two strains that can be connected by a line that starts without an arrowhead and ends with an arrowhead. Abbreviations as in fig. 1.

P. mirabilis and Bacteroides sp. could not be quantified with accuracy, but were lower than the phagocytic index of S. typhimurium. When the phagocytic uptake of this strain of $P$. mirabilis (M13) was studied previously with mice purchased from a different animal supplier, $1 \mathrm{ml}$ of peritoneal mononuclear cell suspension contained an average of $\log _{10} 4.8 P$. mirabilis cells. ${ }^{33}$

To verify that the washed peritoneal exudate cells did not contain adherent extracellular bacteria at the outset of the assay for intracellular survival, they were viewed by scanning electronmicroscopy. At least 200 leucocytes were observed for each bacterial strain tested. No adherent extracellular bacteria were seen except for $P$. mirabilis, 2-10 cells of which were seen adhering to one in 20 leucocytes.

\section{Intracellular survival of eight strains of intestinal bacteria in peritoneal mononuclear phagocytes}

The intracellular survival of eight bacterial strains is presented as the percentage survival after $0,30,60$ and $120 \mathrm{~min}$ (fig. 2) and as the intracellular killing constant $\left(\mathrm{K}_{\mathrm{k}}\right)$ during the period of $120 \mathrm{~min}$ (fig. 3). According to the formula for $K_{k}$, a negative value would indicate an increase in the numbers of intracellular bacteria, a 
Table IV. Relationship between oral infectivity of 10 bacterial strains and their phagocytic uptake and intracellular survival in mononuclear phagocytes

\begin{tabular}{llll}
\hline Strain & Oral infectivity* & Phagocytic uptake $\dagger$ & Intracellular survival* \\
\hline S. typhimurium 14028 & Very high & Low & Intermediate \\
L. monocytogenes + H1a & High & High & High \\
L. monocytogenes - H1a & Intermediate & High & High \\
L. monocytogenes + H4b & Intermediate & High & Intermediate \\
Ent. faecalis M20 & Intermediate & High & High \\
E. coli C25 & Intermediate & Low & Low \\
E. coli M14 & Intermediate & Low & Low \\
P. mirabilis M13 & Intermediate & Low & Low \\
B. fragilis 9032 & Low & Low & Intermediate \\
Bacteroides sp. M25 & Low & Low & Not tested \\
& & & \\
\hline
\end{tabular}

* Relative infectivity based on information in table I.

†Relative phagocytic uptake based on information in fig. 1 and reference 33.

$\ddagger$ Relative intracellular survival based on information in fig. 3 and reference 33 .

result not observed with any of the strains tested. As shown in fig. 2, all strains decreased in number during the $120 \mathrm{~min}$ of this assay. Surprisingly, the three strains best able to survive intracellularly were $L$. monocytogenes + H1a and $-\mathrm{H} 1 \mathrm{a}$ and Ent. faecalis, with $>60 \%$ of the intracellular bacteria persisting for $120 \mathrm{~min}$ (fig. 2). This result was reflected in correspondingly low $K_{k}$ values (fig. 3). Another surprising result was that the $\mathrm{K}_{\mathrm{k}}$ of $S$. typhimurium (a relatively virulent organism) was not significantly different from that of the relatively avirulent $\boldsymbol{B}$. fragilis. The general observation was that intracellular survival (fig. 3) was not consistently correlated with oral infectivity (table I).

Because we could not eliminate sufficient numbers of extracellular bacteria, the intracellular survival of $P$. mirabilis and a Bacteroides sp. could not be accurately quantified. In a previous study, ${ }^{33}$ slightly more $P$. mirabilis were ingested than in the present study, permitting repeated centrifugation to remove sufficient numbers of extracellular $P$. mirabilis (i.e., resulting in 10-fold fewer extracellular $P$. mirabilis than intracellular bacteria). In this latter study, E. coli M14 was also tested, its intracellular survival being similar to that of $P$. mirabilis M13.

\section{Discussion}

The results showed (tables II and III) that pathogenic species, such as $S$. typhimurium and L. monocytogenes, could translocate after oral inoculation into mice; that facultative species, such as E. coli, translocated after antibiotic-induced intestinal overgrowth; and that strictly anaerobic species, such as $B$. fragilis, translocated only in an occasional mouse even after antibiotic-induced overgrowth. These studies of bacterial translocation were performed so that strains with a documented spectrum of oral infectivity could be tested for their ability to interact with mononuclear phagocytes. These results are summarised in table IV.

In studying the interactions between salmonella and macrophages, Wells and $\mathrm{Hsu}^{42}$ concluded that the virulence of salmonella strains was inversely related to the phagocytic index. S. typhimurium, a virulent strain in our study (table I), was relatively resistant to phagocytosis (fig. 1). However, P. mirabilis and a Bacteroides sp. were even more resistant to phagocytosis than $S$. typhimurium, yet these two strains were clearly less virulent than $S$. typhimurium. Curiously, $L$. monocytogenes strains $+\mathrm{Hla},-\mathrm{Hla}$ and $+\mathrm{H} 4 \mathrm{~b}$, and Ent. faecalis had similar phagocytic indices (fig. 1), yet these stains differed in oral infectivity (table I). Therefore, the degree of bacterial phagocytosis by mouse mononuclear phagocytes was not correlated with oral infectivity in mice (table IV).

Because salmonellae and listeria translocate from the intestine with relative ease,,$^{2-5}$ we postulated that their ability to survive in mononuclear phagocytes ${ }^{21-23}$ might be associated with oral infectivity. None of the strains appeared to multiply in mouse mononuclear phagocytes, including the orally invasive $S$. typhimurium and L. monocytogenes + Hla (figs. 2 and 3). This is not an unusual observation. Czuprynski et al $^{43}$ used proteose peptone-elicited mouse macrophages in a similar antibiotic-free assay and observed that the numbers of viable intracellular $L$. monocytogenes decreased by $c$. $\log _{10} 0.5$ in $2 \mathrm{~h}$. Buchmeier and Heffron $^{24,44}$ reported that $S$. typhimurium 14028 (the strain used in the present study) survived moderately well in splenic and bone marrow-derived macrophages, but less well in peritoneal macrophages (resident and proteose peptone-elicited). $\mathrm{Hsu}^{3}$ concluded that the pathogenesis of salmonellosis was unlikely to be directly related to the ability of the organisms to survive in host macrophages. Thus, our observations that salmonella and listeria did not survive efficiently (or multiply) in mononuclear phagocytes were consistent with those of others.

We expected that pathogenic Salmonella and Listeria strains would survive better intracellularly than species of the normal enteric microflora. This expectation was sometimes but not always fulfilled. Buchmeier and Heffron ${ }^{44}$ recently compared S. typhimurium 14028 with two $E$. coli strains and noted that it survived intracellularly and inhibited macrophage 
phagosomal-lysosomal fusion to a greater extent than did the E. coli strains. Consistent with this observation, intracellular $S$. typhimurium 14028 survived significantly better than the two E. coli strains (fig. 3). However, several other observations were inconsistent. For example, intracellular survival of the relatively avirulent $B$. fragilis was similar to that of $S$. typhimurium, L. monocytogenes $+\mathrm{H} 4 \mathrm{~b}$ and the two $E$. coli strains (fig. 3). Also, there were no significant differences in intracellular survival between $L$. monocytogenes strains $+\mathrm{Hla}$ and $-\mathrm{Hla}$ and Ent. faecalis. As summarised in table IV, when all the bacterial strains in this study were considered as a group, survival within mononuclear phagocytes (fig. 3) was not consistently correlated with oral infectivity (table I).

Because listeriolysin has been considered a primary virulence factor for L. monocytogenes, ${ }^{5,26-27.45-46}$ some comment seems appropriate. Kuhn et al. ${ }^{45}$ observed that, after oral inoculation, bacterial translocation to extra-intestinal tissues occurred with a haemolytic $L$. monocytogenes strain, but not with a non-haemolytic mutant. Using two of the L. monocytogenes strains of the present study, others have reported that $-\mathrm{Hla}$ was relatively avirulent compared to $+\mathrm{Hla}$ by either the oral ${ }^{4}$ or the intraperitoneal route. ${ }^{4,26}$ After orally inoculating $L$. monocytogenes $+\mathrm{Hla},-\mathrm{Hla}$, and $+\mathrm{H} 4 \mathrm{~b}$ into mice, we agree with Kathariou et al. ${ }^{47}$ and Tabouret et al. ${ }^{29}$ who concluded that listeriolysin production was not directly proportional to virulence for mice. Kuhn et al ${ }^{45}$ noted that haemolysin production had no effect on uptake of listeria by mouse peritoneal macrophages. In the present study, differ-

\section{References}

1. Finlay BB, Falkow S. Common themes in microbial pathogenicity. Microbiol Rev 1989; 53: 210-230.

2. Wells CL, Maddaus MA, Simmons RL. Proposed mechanisms for the translocation of intestinal bacteria. Rev Infect Dis $1988 ; 10$ : 958-979.

3. Hsu HS. Pathogenesis and immunity in murine salmonellosis. Microbiol Rev 1989; 53: 390-409.

4. Pine L, Malcolm GB, Plikaytis BD. Listeria monocytogenes intragastric and intraperitoneal approximate $50 \%$ lethal doses for mice are comparable, but death occurs earlier by intragastric feeding. Infect Immun 1990; 58: 2940-2945.

5. Roll JT, Czuprynski CJ. Hemolysin is required for extraintestinal dissemination of Listeria monocytogenes in intragastrically inoculated mice. Infect Immun 1990; 58: 3147 3150 .

6. Berg RD, Garlington AW. Translocation of certain indigenous bacteria from the gastrointestinal tract to the mesenteric lymph nodes and other organs in a gnotobiotic mouse model. Infect Immun 1979; 23: 403-411.

7. Steffen EK, Berg RD, Deitch EA. Comparison of translocation rates of various indigenous bacteria from the gastrointestinal tract to the mesenteric lymph node. $J$ Infect Dis $1988 ; 157$ : 1032-1038.

8. Wells CL, Jechorek RP, Maddaus MA. The translocation of intestinal facultative and anaerobic bacteria in defined flora mice. Microb Ecol Health Dis 1988; 1 : 227-235.

9. Wells CL, Erlandsen SL. Localization of translocating Escherichia coli, Proteus mirabilis, and Enterococcus faecalis within cecal and colonic tissues of monoassociated mice. Infect Immun 1991; 59: 4693-4697.

10. Wells CL, Jechorek RP, Gillingham KJ. Relative contributions ences in phagocytic uptake of $L$. monocytogenes $+\mathrm{Hla},+\mathrm{H} 4 \mathrm{~b}$ and $-\mathrm{H}$ la were not significant (fig. 1). Kuhn et al $^{48}$ also reported that loss of haemolysin (transposon-induced mutation) reduced intracellular survival. In the present study, intracellular survival was not consistently correlated with haemolysin production; L. monocytogenes $+\mathrm{Hla}$ and $-\mathrm{H} 1 \mathrm{a}$ produced 512 and 32 haemolytic units, respectively, yet these strains had similar intracellular survival. Furthermore, the intracellular survival of both $+\mathrm{Hla}$ and $-\mathrm{Hla}$ was significantly better than that of $+\mathrm{H} 4 \mathrm{~b}$, an intermediate haemolysin producer. However, listeriolysin is not the only virulence factor in L. monocytogenes, ${ }^{27,45.47-48}$ and in a recent review, Portnoy et al. ${ }^{49}$ summarised information on a number of genes with products that probably participate in pathogenicity.

In conclusion, the results indicated that the ability of a bacterial strain to interact with mononuclear phagocytes was not consistently associated with oral infectivity (table IV). As a caveat, it should be mentioned that proteose peptone-elicited peritoneal mononuclear cells were tested in these experiments and that either unelicited mononuclear phagocytes or mononuclear phagocytes from other tissues (e.g., spleen, liver, bone marrow) might have behaved differently. However, this study suggests that oral infectivity is not generally correlated with bacterial uptake or intracellular survival in mononuclear phagocytes.

We thank Diane Bierman and Muriel Gavin for excellent technical assistance. This work was supported by Public Health Service grant AI 23484 from the United States National Institutes of Health.

of host and microbial factors in bacterial translocation Arch Surg 1991; 126: 247-252.

11. Penn RL, Nguyen VQ, Specian RD, Stevens P, Berg RD. Interleukin-2 enhances the translocation of Escherichia coli from the intestines to other organs. J Infect Dis 1991; 164 : 1168-1172.

12. van der Waaij DJ, Berghuis-de Vries M, Lekkerkerk-van der Wees JEC. Colonization resistance of the digestive tract and the spread of bacteria to the lymphatic organs in mice. J Hyg 1972; 70: 335-342.

13. Wells CL, Jechorek RP, Erlandsen SL. Evidence for the translocation of Enterococcus faecalis across the mouse intestinal tract. $J$ Infect Dis $1990 ; 162: 82-90$.

14. Wells CL, Jechorek RP, Maddaus MA, Simmons RL. Effects of clindamycin and metronidazole on the intestinal colonization and translocation of enterococci in mice. Antimicrob Agents Chemother 1988; 32: 1769-1775.

15. Wells CL, Maddaus MA, Jechorek RP, Simmons RL. Ability of intestinal Escherichia coli to survive within mesenteric lymph nodes. Infect Immun 1987; 55: 2834-2837.

16. Wells CL, Maddaus MA, Reynolds CM, Jechorek RP, Simmons RL. Role of anaerobic flora in the translocation of aerobic and facultatively anaerobic intestinal bacteria. Infect Immun 1987; 55 : 2689-2694.

17. Wells CL. Relationship between intestinal microecology and the translocation of intestinal bacteria. Antonie van Leeuwenhoek 1990; 58: 87-93.

18. Freter R, Brickner H, Fekete J, Vickerman MM, Carey KE. Survival and implantation of Escherichia coli in the intestinal tract. Infect Immun 1983; 39: 686-703.

19. Wells CL, Maddaus MA, Erlandsen SL, Simmons RL. Evidence for the phagocytic transport of intestinal particles in dogs and rats. Infect Immun 1988; 56: 278-282. 
20. Harmsen AG, Muggenburg BA, Snipes MB, Bice DE. The role of macrophages in particle translocation from lungs to lymph nodes. Science $1985 ; 230$ : 1277-1280.

21. Mackaness GB. Cellular resistance to infection. J Exp Med 1962; 116: 381-406.

22. Moulder JW. Comparative biology of intracellular parasitism. Microbial Rev 1985; 49: 298-337.

23. North RJ. The relative importance of blood monocytes and fixed macrophages to the expression of cell-mediatedimmunity to infection. J Exp Med 1970; 132: 521-534.

24. Buchmeier NA, Heffron F. Intracellular survival of wild-type Salmonella typhimurium and macrophage-sensitive mutants in diverse populations of macrophages. Infect Immun 1989; 57: 1-7.

25. Fields PI, Swanson RV, Haidaris CG, Heffron F. Mutants of Salmonella typhimurium that cannot survive within the macrophage are avirulent. Proc Natl Acad Sci 1986; 83: 5189-5193.

26. Pine L, Weaver RE, Carlone GM et al. Listeria monocytogenes ATCC 35152 and NCTC 7973 contain a nonhemolytic, nonvirulent variant. J Clin Microbiol 1987; 25: 2247-2251.

27. Kathariou S, Pine L, George V, Carlone GM, Holloway BP. Nonhemolytic Listeria monocytogenes mutants that are also noninvasive for mammalian cells in culture: evidence for coordinate regulation of virulence. Infect Immun 1990; 58: $3988-3995$.

28. Sutter VL, Citron DM, Edilstein AC, Finegold SM. Wadsworth anaerobic bacteriology manual, 4th edn. Belmont, CA, Star Publishing Co.

29. Tabouret M, De Rycke J, Audurier A, Poutrel B. Pathogenicity of Listeria monocytogenes isolates in immunocompromised mice in relation to listeriolysin production. $J$ Med Microbiol 1991; 34: 13-18.

30. Geoffroy C, Gaillard J-L, Alouf JE, Berche P. Purification, characterization, and toxicity of sulfhydryl-activated hemolysin listeriolysin $\mathrm{O}$ from Listeria monocytogenes. Infect Immun 1987; 55: 1641-1646.

31. Zachar Z, Savage DC. Microbial interference and colonization of the murine gastrointestinal tract by Listeria monocytogenes. Infect Immun 1979; 23: 168-174.

32. Leijh PCJ, van Furth $R$, van Zwet TL. In vitro determination of phagocytosis and intracellular killing by polymorphonuclear leukocytes and mononuclear phagocytes. In: Weir DM (ed) Handbook of experimental immunology, vol 2. Cellular immunology. Oxford, Blackwell Scientific Publications. $1986: 46 \cdot 1-46 \cdot 21$.

33. Wells CL, Jechorek RP, Nelson RD. Interactions of Escherichia coli and Proteus mirabilis with mononuclear phagocytes. J Med Microbiol 1990; 33: 153-163.

34. van Dissel JT, Leijh PCJ, van Furth R. Differences in initial rate of intracellular killing of Salmonella typhimurium by resident peritoneal macrophages from various mouse strains. J Immunol 1985; 134: 3404-3410.
35. Balows A. Manual of clinical microbiology, 5th edn. American Society for Microbiology, Washington, D.C. 1991.

36. Ofek I, Sharon N. Lectinophagocytosis: a molecular mechanism of recognition between cell surface sugars and lectins in the phagocytosis of bacteria. Infect Immun 1988; 56: 539-547.

37. Harrington-Fowler L, Henson PM, Wilder MS. Fate of Listeria monocytogenes in resident and activated macrophages. Infect Immun 1981; 33: 11-16.

38. Jones T, Youmans GP. The in vitro inhibition of growth of intracellular Listeria monocytogenes by lymphocyte products. Cell Immunol 1973; 9: 353-362.

39. Cole P, Brostoff J. Intracellular killing of Listeria monocytogenes by activated macrophages (Mackaness system) is due to antibiotic. Nature 1975; 256: 515-517.

40. Patterson RJ, Youmans GP. Multiplication of Mycobacterium tuberculosis within normal and "immune" mouse macrophages cultivated with and without streptomycin. Infect Immun 1970; 1: 30-40.

41. Czuprynski CJ, Campbell PA, Henson PM. Killing of Listeria monocytogenes by human neutrophils and monocytes, but not monocyte-derived macrophages. $J$ Reticuloendothel Soc $1983 ; 34: 29-44$.

42. Wells PS, Hsu HS. Interactions between macrophages of guinea pigs and salmonellae. II. Phagocytosis of Salmonella typhimurium by macrophages of normal guinea pigs. Infect Immun 1970; 2: 145-149.

43. Czuprynski CJ, Henson PM, Campbell PA. Killing of Listeria monocytogenes by inflammatory neutrophils and mononuclear phagocytes from immune and nonimmune mice. $J$ Leukoc Biol 1984; 35: 193-208.

44. Buchmeier NA, Heffron F. Inhibition of macrophage phagosome-lysosome fusion by Salmonella typhimurium. Infect Immun 1991; 59: 2232-2238.

45. Kuhn M, Kathariou S, Goebel W. Hemolysin supports survival but not entry of the intracellular bacterium Listeria monocytogenes. Infect Immun 1988; 56: 79-82.

46. Sun AN, Camilli A, Portnoy DA. Isolation of Listeria monocytogenes small-plaque mutants defective for intracellular growth and cell-to-cell spread. Infect Immun 1990; 58: 3770-3778.

47. Kathariou S, Rocourt J, Hof H, Goebel W. Levels of Listeria monocytogenes hemolysin are not directly proportional to virulence in experimental infections of mice. Infect Immun $1988 ; 56,534-536$.

48. Conlan JW, North RJ. Roles of Listeria monocytogenes virulence factors in survival: virulence factors distinct from listeriolysin are needed for the organism to survive an early neutrophil-mediated host defense mechanism. Infect Immun 1992; 60: 951-957.

49. Portnoy, DA, Chakraborty T, Goebel W, Cossart P. Molecular determinants of Listeria monocytogenes pathogenesis. Infect Immun 1992; 60: 1263-1267. 